IN addition to its well-established effect on $\mathrm{T}$ cells, cyclosporin A (CsA) also inhibits in flammatory cytokine production by macrophages. However, little is known about the mechanism of action of CsA on macrophage cytokine production. We measured the effect of CsA on basal and phorbol-myristate-acetate (PMA)-stimulated production of in terleukin-6 using the human monocyte cell line U937 differentiated with dimethylsulfoxide (DMSO). Interleukin-6 levels were measured in supernatant and cell lysates using specific enzyme-linked immunosorbent assays. We found that CsA decreases not only IL-6 release but also cytokine synthesis. The concentration of CsA used did not affect either cell viability or proliferation. Three possibilities may be advanced to explain the CsA-due decrease in IL-6 production by macrophages: (a) inhibition of the synthesis of an early common regulatory protein, (b) inhibition of cytokine gene transcription, or (c) modulation of post-transcriptional events. The first possibility was tested by measuring the effect of cycloheximide on the experimental system during the first 3 hours of culture. Although cycloheximide decreased total cytokine synthesis, the pattern of cytokine modulation by CsA persisted. These data suggest that CsA-mediated macrophage cytokine inhibition is not mediated by an early common regulatory protein. To further explore the inhibition mechanis $m$, we measured IL-6 mRNA levels by Northern blot. IL-6 mRNA levels were unaffected by CsA both in resting and PMA-stimulated cells. We conclude that in human macrophages CsA diminishes IL-6 production at post-transcriptional level.

Key words: Cyclosporin A, Interleukin-6, Macrophage, U937.

\section{Cyclosporin A decreases human macrophage interleukin- 6 synthesis at post-transcriptional level}

\author{
Juan E. Losa García ${ }^{1, C A}$, Ana M. Rodríguez López², \\ María Rosa Martín de Cabo ${ }^{3}$, \\ Fernando Mateos Rodríguez ${ }^{4}$, Jesús Pérez Losada ${ }^{5}$, \\ Rogelio González Sarmiento ${ }^{5}$, \\ Antonio Jiménez López ${ }^{5}$ and \\ José Luis Pérez Arellano6
}

${ }^{1}$ Area de Medicina. Fundación Hospital de Alcorcón, ${ }^{2}$ Departmento de Fisiología. Universidad de Salamanca, ${ }^{3}$ Centro de Salud Miguel Servet. Alcorcón, ${ }^{4}$ Hospital General de Albacete, ${ }^{5}$ Departmento de Medicina. Universidad de Salamanca, and ${ }^{6}$ Departamento de Ciencias Clínicas. Universidad de Las Palmas, Spain.

${ }^{\mathrm{CA}}$ Corresponding Author

Internal Medicine Unit, Fundación Hospital de Alcorcón, Budapest 1, 28922 Alcorcón, Madrid, Spain Tel: $(+349) 16219513$

Fax: (+349) 16219901

Email: jelosa@fhalcorcon.es

\section{Introduction}

Cyclosporin A (CsA) is an immunomodulatory substance used in the prevention of transplant rejection and in the treatment of autoimmune disease. ${ }^{1}$ Classically, CsA has been reported to exert its immunomodulatory action through its effect on T lymphocytes, mainly helper $\mathrm{T}$ lymphocytes, by inhibiting calcine urin dependent interleukin-2 synthesis. ${ }^{2,3}$ Recently, however, it has been suggested that the inhibition of T lymphocyte activation by CsA does not appropriately account for all the effects observed following in vivo administration of the drug. ${ }^{4}$ Accordingly, despite widespread use of the drug, the specific mechanis $m$ of action of CsA remains to be fully elucidated. ${ }^{5}$ It is also possible that its effects could be due in part to the action of CsA on other cells. ${ }^{6}$ In th is sense, it should be noted that CsA binds specifically, reversibly and in a time-and temperature-dependent fashion to all human leucocytes. However, granulocytes and cells of the mononuclear phagocyte system
(MPS) sometimes bind more CsA than lymphocytes, probably because the drug is rapidly internalized. ${ }^{2,7}$

Cells of the MPS offer an attractive possibility to study the effects of this drug because they participate in a crucial manner in antigen presentation and, in many cases, are the final effectors of the immune system. Many references in the literature report the capacity of CsA to alter the activities of MPS cells. In general, the capacities, functions and actions of macrophages related to non-specific defense such as chemotaxis, phagocytosis, enzyme release and respiratory burst, can be said to be more resistant to CsA. ${ }^{8,9}$ By contrast, those related to immunoregulation or accessory functions, such as monokine production, the expression of his tocompatibility antigens and antigen presentation, are more susceptible to the action of CsA. ${ }^{8,9}$

Macrophages synthesize and secrete IL-1 $\beta$, TNF- $\alpha$, IL-6 and IL-8. ${ }^{10}$ These monokines are know $n$ mediators of the inflammatory response ${ }^{10}$ and are therefore also known as inflammatory cytokines. It has been 
reported that CsA inhibits the production of IL-1 $\beta$, TNF- $\alpha$ and IL- 6 in different cells of the MPS. ${ }^{11,12}$ However, the mechanism through which this occurs is not well know n. ${ }^{13}$

In the light of the foregoing, the aim of the present study was to evaluate and determine the mechanism of action of CsA on the production of inte rleukin- 6 by macrophages. To do so, the human differentiated U937 monocyte line was employed.

\section{Methods}

\section{Cell line}

U937 cells were kindly supplied by Dr J. Olmos of the Hospital Universitario Marqués de Valdecilla, Santande r (Spain). The cell line was kept at $37^{\circ} \mathrm{C}$ in a humidified atmosphere with $5 \% \mathrm{CO}_{2}$ in culture with complete medium containing RPMI 1640 (Sigma $\left.{ }^{\circledR}\right), \quad 100 \mathrm{U} / \mathrm{mL}$ of penicillin (Sigma $\left.{ }^{\circledR}\right)$, $100 \mathrm{U} / \mathrm{mL}$ of streptomycine (Sigma $\left.{ }^{\circledR}\right), \quad 2 \mathrm{mM}$ L-glutamine (Sigma ${ }^{\circledR}$ ) and $10 \%$ fetal calf serum (FCS) $\left(\right.$ Gibco $\left.{ }^{\circledR}\right)$ in sterile culture flasks (Nunclon ${ }^{\circledR}$ ) at a concentration between $0.75 \times 10^{5}$ and $5 \times 10^{5}$ cells $/ \mathrm{mL}$. Cell viability was greater than $90 \%$ and the duplication time was between 24 and 48 hours. Cells were regularly screened for lipopolysaccharide (LPS), bacteria, mycoplasma and fungal contamination and found to be negative. Cells were differentiated by culture over 4 days in complete medium containing $1.3 \%$ dimethylsulfoxide (DMSO).

\section{Cell cultures}

$5 \times 10^{5}$ cells together with different stimuli and/or CsA at the following concentration were added to each well of the culture dishes (Costar $\left.{ }^{\circledR}\right)$ with complete medium: Lipopolysaccharide from E. coli (Sigma ${ }^{\circledR}$ ) at $100 \mu \mathrm{g} / \mathrm{mL}$ and $10 \mu \mathrm{g} / \mathrm{mL}$; phorbol12 -myristate-13-acetate (PMA) (Sigma ${ }^{\circledR}$ ) at $10^{-4} \mathrm{M}$ and $10^{-5} \mathrm{M}$; human gamma-interferon (Sigma ${ }^{\circledR}$ ) at $1000 \mathrm{U} / \mathrm{mL}$ and $100 \mathrm{U} / \mathrm{mL}$ and CsA (Sandoz ${ }^{\circledR}$ ) at three non-toxic concentrations in vivo: 200, 20 and $2 \mathrm{ng} / \mathrm{mL}$.

Cells were kept at $37^{\circ} \mathrm{C}$ in a humified atmosphere with $5 \% \mathrm{CO}_{2}$ for 18 hours, after which the supernatants were centrifuged at $500 \mathrm{~g}$ for $10 \mathrm{~min}$ to sediment cells in suspension and then stored at $-70^{\circ} \mathrm{C}$ until later determination.

After the supernatant had been removed, $400 \mu \mathrm{L}$ of a $0.25 \mathrm{M}$ sucrose-0.02 EDTA solution was added to each well. After the bottom of each well had been scraped vigorously, the content was aspirated and added to the previous cell pellet, thus recovering all the cells. The cells were then subjected to heat disintegration by repeated freezing-thaw ing (6 cycles of $10 \mathrm{~min}$ freezing and $15 \mathrm{~min}$ thawing) and were stored at $-70^{\circ} \mathrm{C}$ until determination.
To study the inhibition of early protein synthesis, cycloheximide (Sigma ${ }^{\circledR}$ ) at a concentration of $1 \mu \mathrm{g} / \mathrm{mL}$ was added during the first 3 hours of cell culture.

\section{Cytokine determination}

The inflammatory cytokine IL-6 was determined by direct double-sandwich enzyme-linked immunosorbent assay (ELISA) of antibodies in the supernatants and cell lysates. BIOTRAK® (Ame rsham, UK) commercial kit specific for human IL-6 was used; this showed no cross-reactivity with other cytokines. It had a coefficient of variation less than $10 \%$ and a sensitivity limit of $0.35 \mathrm{pg} / \mathrm{mL}$. All samples were measured in duplicate. Results were expressed in picograms $/ 10^{6}$ cells. It should be noted that in ELISA assays none of the components of the culture medium (RPMI 1640, antibiotics, glutamine or fetal calf serum) showed immunoreactivity with the cytokine studied.

\section{IL-6 mRNA expression}

Transcription of the IL- 6 gene was studied by Northern blot. Differentiated U937 cytoplasmic RNA was isolated by $150 \mathrm{mM} \mathrm{NaCI}, 1 \mathrm{mM} \mathrm{MgCI} 2,10 \mathrm{mM}$ TrisHCI pH 7.4, 0.5\% Nonidet $\mathrm{P} 40$ and $250-1000 \mathrm{U} / \mathrm{mL}$ RNAsing (Promega ${ }^{\circledR}$ ) lysis, followed by two successive ultracentrifugations with Tris-buffered phenol and $10 \%$ SDS and phenol, respectively. RNA was precipitated overnight with cold ethanol and $3 \mathrm{M}$ sodium acetate $\mathrm{pH} 7.2$, and redissolved in Tris-EDTA pH 7 buffer. RNA was quantified by determining optical density at a wavelength of $260 \mathrm{~nm}$. The quality of the RNA was checked by the demonstration of two bands corresponding to ribosomal RNA (18s and 28s) and the absence of degradation of the RNA by staining with ethidium bromide in the electrophoresis of a $1 \%$ agarose minigel loaded with $1.5 \mu \mathrm{g}$ of RNA.

RNA was denatured by incubation for $1 \mathrm{~h}$ at $50^{\circ} \mathrm{C}$ in a solution of $1 \mathrm{M}$ glyoxal, $50 \%$ DMSO and $10 \mathrm{mM}$ $\mathrm{NaH}_{2} \mathrm{PO}_{4}$. Following this, $5 \mu \mathrm{g}$ of RNA were mixed with electrophoresis sample buffer $(50 \%$ glycerol, $49.6 \% 10 \mathrm{mM} \mathrm{NaH}_{2} \mathrm{PO}_{4} \mathrm{pH} 7.0,0.4 \%$ bromophenol blue). After loading samples, electrophoresis (35V) was carried out in $1 \%$ agarose $-10 \mathrm{mM} \mathrm{NaH}_{2} \mathrm{PO}_{4} \mathrm{pH} 7$ gels using $10 \mathrm{mM} \mathrm{NaH} \mathrm{PO}_{4} \mathrm{pH} 7$ buffer. Following electrophoresis, the RNA was transferred overnight by capillarity from the gel to a nitrocellulose membrane using $20 \times$ SSC. This membrane was dried with Whatman paper and the RNA was cross-linked to the membrane by exposure to UV light. Then, the membrane was prehybridized for $2 \mathrm{~h}$ at $65^{\circ} \mathrm{C}$ in a solution containing $6.4 \%$ dex tran, $3 \times$ SSC, $1 \times$ Denhart's, $0.1 \%$ SDS and $250 \mu \mathrm{g} / \mathrm{mL}$ heat-denatured salmon sperm DNA. IL-6 cDNA and G3PDH cDNA probes commercialized by the American Type Culture Collection (ATCC) were labelled with ${ }^{32} \mathrm{P}$ using 
the commercial 'Ready To Go' kit (Pharmacia Biotech $\left.{ }^{\circledR}\right)$ following the protocol indicated by the manufacturer. Hybridization $\left(18 \mathrm{~h}, 65^{\circ} \mathrm{C}\right)$ was carried out using the same prehybridization solution containing heat-denature d ${ }^{32} \mathrm{P}$-labelled probes. Following successive washings in 0.1 SDS-0, 1 SSC at room temperature and $65^{\circ} \mathrm{C}$, respectively, membranes were blotted dry and used for autoradiography with XR film (Cronex 105, Dupont ${ }^{\circledR}$ ) at $-70^{\circ} \mathrm{C}$ over 6 days. Hybridization with the G3PDH probe was used as an RNA loading control for blots.

\section{Results}

\section{Differentiation of the U937 line}

The data (not shown) confirming that suitable differentiation of the monocyte cell line toward macrophage cells had been achieved were as follows:

- a decrease in the cellular proliferation rate without viability being affected;

- an increase in adherence to the culture supports and among cells;

- an increased cytoplasm, the disappearance of nuclear polylobulation and a decrease in nuclear atypias and the number of nucleoli;

- an increase in the content of macrophage enzymes (non-specific esterases); and

- an increase in cytoplasmic RNA content.
Determination of type of stimulus and most effective concentration on interleukin- 6 secretion

In order to study the most suitable type of stimulus for inducing the secretion of IL- 6 and the most effective concentration, U937 cells were used under both differentiated and undifferentiated conditions. Three classic stimuli were studied at two different concentrations: lipopolysaccharide (LPS), phorbol myris tate acetate (PMA) and gamma-interferon ( $\gamma$-IFN). The mean values of the results of the study carried out in quadruplicate are shown in Fig. 1. Overall, the data obtained indicate that the most potent stimulus of cytokine secretion was PMA at a concentration of $10^{-5} \mathrm{M}$. IL-6 secretion was greater by differentiated U937 cells than by undifferentiated ones.

\section{Effect of CsA on the synthesis of interleukin-6}

The results of the effect of diffe rent concentrations of CsA on IL-6 secretion under both basal and stimulated conditions are show $\mathrm{n}$ in Table 1 . These data show the mean values obtained in four different assays. As may be seen, both in undifferentiated and differentiated U937 cells, at the highest concentration used (200 ng/ $\mathrm{mL}$ ) CsA decreased stimulated secretion of IL-6. CsA can be said to decrease the secretion of this cytokine more than $50 \%$ The effect of CsA on basal IL-6 secretion was much lower.
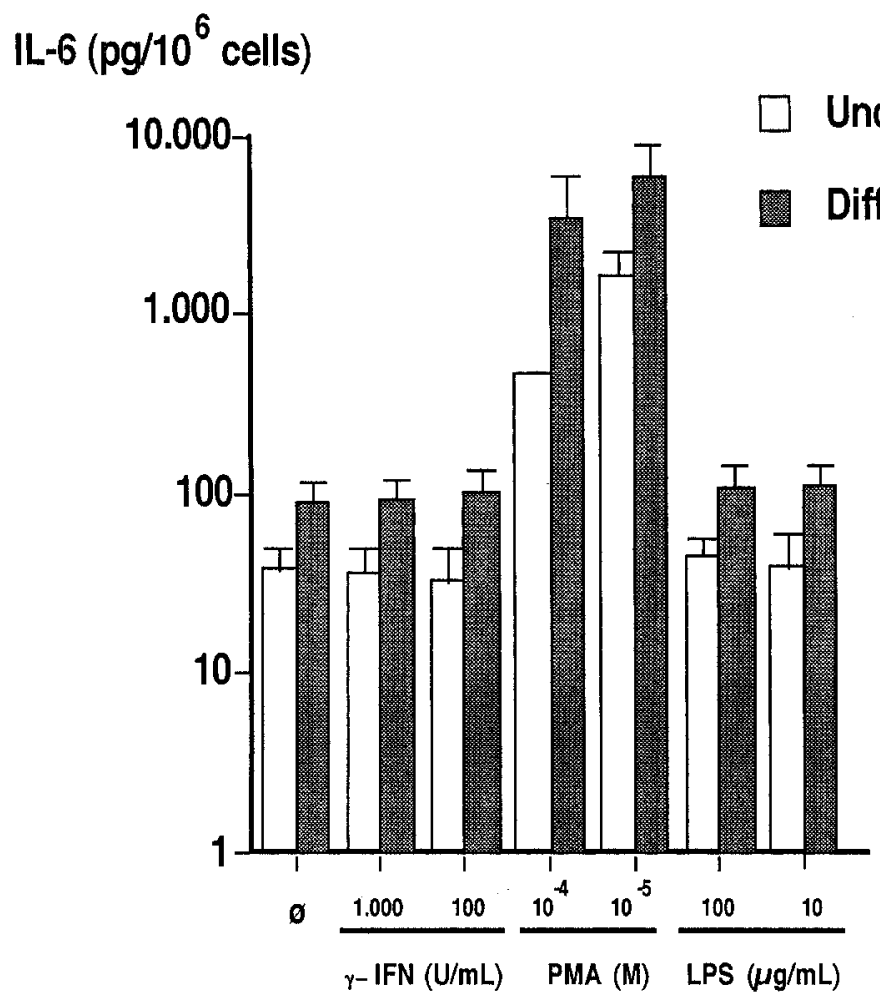

FIG. 1. Effect of different stimuli on IL-6 secretion by U937 cells. The most potent stimulus of cytokine secretion was PMA at a concentration of $10^{-5} \mathrm{M}$. Definition of abbreviations: IFN, interferon; IL-6, interleukin-6; LPS, lipolysaccharide; PMA, phorbol myristate acetate. Note the logaritmic scale. 
Table 1. Effect of CsA on basal and stimulated IL- 6 secretion by $U 937$ cells ( $\mathrm{pg} / 10^{6}$ cells). Both in undifferentiated and differentiated U937 cells, at the highest concentration used (200 ng/mL) CsA decreased stimulated secretion of IL-6. Definition of abbreviations: CsA, cyclosporin A; PMA, phorbol myristate acetate; SEM, standard error of mean.

\begin{tabular}{|c|c|c|}
\hline & Mean & SEM \\
\hline \multicolumn{3}{|l|}{ Undifferentiated } \\
\hline Basal & 38,4 & 7,9 \\
\hline$+\operatorname{CsA}\left(2 n g L^{-1}\right)$ & 37,6 & 13,1 \\
\hline$+\operatorname{CsA}\left(20 \mathrm{ng} \mathrm{mL}^{-1}\right)$ & 34,0 & 12,7 \\
\hline$+\operatorname{CsA}\left(200 \mathrm{ng} \mathrm{mL}^{-1}\right)$ & 25,2 & 4,2 \\
\hline+ PMA $10^{-5} \mathrm{M}$ & 1705,1 & 313,5 \\
\hline$+\mathrm{CsA}\left(200 \mathrm{ng} \mathrm{mL}^{-1}\right)$ & 731,4 & 66,0 \\
\hline \multicolumn{3}{|l|}{ DMSO differentiated } \\
\hline Basal & 90,4 & 27,6 \\
\hline$+\operatorname{CsA}\left(2 \mathrm{ng} \mathrm{mL}^{-1}\right)$ & 99,7 & 33,3 \\
\hline$+\operatorname{CsA}\left(20 \mathrm{ng} \mathrm{mL}^{-1}\right)$ & 91,4 & 34,2 \\
\hline$+\mathrm{CsA}\left(200 \mathrm{ng} \mathrm{mL}^{-1}\right)$ & 67,1 & 20,6 \\
\hline+ PMA $10^{-5} \mathrm{M}$ & 6343,7 & 3135,6 \\
\hline$+\mathrm{CsA}\left(200 \mathrm{ng} \mathrm{mL}^{-1}\right)$ & 2035,1 & 1072,6 \\
\hline
\end{tabular}

Using U937 cells differentiated with 1.3\% DMSO, the intracellular content of IL-6 was measured after stimulation with phorbol myristate in two different assays. At $200 \mathrm{ng} / \mathrm{mL}$, CsA decreased the intracellular content of IL-6 from $151,0 \pm 97,2$ to $100,0 \pm 61,3 \mathrm{pg} /$ $10^{6}$ cells. So, CsA can be said to decrease the production of cytokines since both the intra-and extracellular contents were affected.

\section{Effect of CsA on cell viability and cell proliferation capacity}

The first and simplest possibility considered was that CsA would affect cell viability and/or prolife ration and hence that the decrease in cytokine production would be due to a decrease in these capacities. Accordingly, a duplicate study was performed in which the prolife ration capacity and cell viability of a U937 line subjected to the same stimuli as those used in the study were evaluated. Table 2 shows the results of this study.

As seen, CsA did not affect either viability or prolife ration capacity, either in undiffe rentiated U937 cells or in cells differentiated with DMSO. Therefore the results on cytokine secretion cannot be interpreted in these terms.

In this study, the effects of several stimulatory substances were also assessed. Both PMA and LPS, but not gamma-interferon, were seen to decrease cell viability.

\section{Effect of cycloheximide on CsA inhibition of IL-6 production}

To study the mechanism by which CsA decreases IL-6 production, three working hypotheses were addressed: that CsA affects the synthesis of an early protein, responsible for the decreased levels of the cytokine; that it exerts its action at transcriptional level, and that its effect is mediated at post-transcriptional level.

The first mechanism proposed was evaluated by treatment $w$ ith cycloheximide (an inhibitor of prote in synthesis) of differentiated U937 cells during the first 3 hours of culture. Prior to this study it was ascertained that cycloheximide does not affect cell viability (data not shown).

The effect of cycloheximide on the secretion of IL-6 is detailed in Fig. 2. As may be seen, although overall this drug decreased both basal and stimulated cytokine secretion in differentiated cells, which was expected, the inhibitory effect of CsA persisted in all cases. It is therefore unlikely that the mechanism of action of CsA would depend on inhibition of the synthesis of an early protein.

\section{Effect of CsA on expression of the IL- 6 gene}

Study of the action of CsA on the expression of IL- 6 mRNA by Northern blot was carried out on the differentiated cell line under both basal and stimulated conditions. Two assays were performed and, in each, Northern blot was implemented in duplicate. Figure 3 shows the results of one of the assays. As may be seen, CsA did not affect the levels of IL-6 mRNA under either basal or stimulated conditions.

Table 2. Effect of CsA and different stimuli on cell proliferation and viability. In this study we started out with a viable cell concentration of $250,000 / \mathrm{mL}$, obtaining the data after 18 hours of culture. CsA did not affect either the viability or proliferation capacity of either differentiated or undifferentiated cells. Additionally, both LPS and PMA, but not interferon, decreased cell viability. Definition of abbreviations: CsA, cyclosporin A; LPS, lipopolysaccharide; PMA, phorbol myristate acetate

\begin{tabular}{|c|c|c|c|c|}
\hline & \multicolumn{2}{|c|}{ Undifferentiated U937 cell line } & \multicolumn{2}{|c|}{ Differentiated U937 cell line } \\
\hline & Viable cells $/ \mathrm{mL}$ & Viability (\%) & Viable cells $/ \mathrm{mL}$ & Viability (\%) \\
\hline Basal conditions & 370.000 & 91 & 317.000 & 95 \\
\hline PMA $10^{-5} \mathrm{M}$ & 240.000 & 84 & 128.000 & 76 \\
\hline LPS $(100 \mu \mathrm{g} / \mathrm{mL})$ & 335.000 & 88 & 280.000 & 88 \\
\hline$\gamma$-Interferon $(1000 \mathrm{U} / \mathrm{mL})$ & 400.000 & 94 & 285.000 & 92 \\
\hline CsA (200 ng/ML) & 385.000 & 94 & 300.000 & 93 \\
\hline $\mathrm{CsA}(200 \mathrm{ng} / \mathrm{mL})+\mathrm{PMA} 10^{-5} \mathrm{M}$ & 240.000 & 77 & 115.000 & 81 \\
\hline
\end{tabular}




\section{IL-6 (pg/10 6 cells)}

Dithout cycloheximide

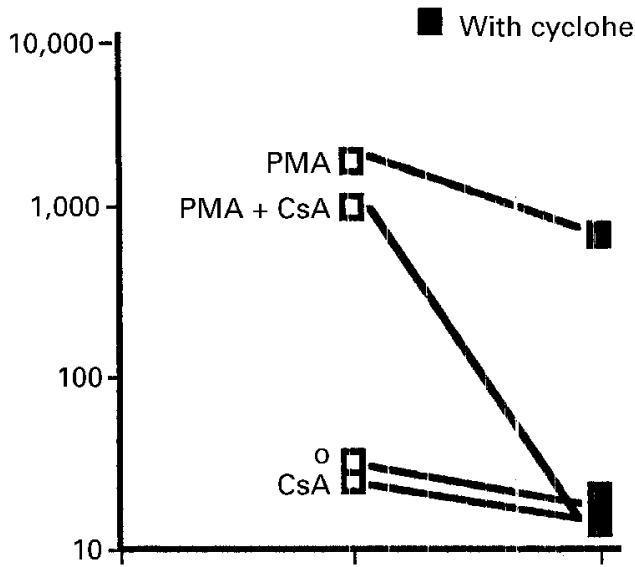

FIG. 2. Effect of cycloheximide on the action of CsA in U937 cells. The effect of cycloheximide was evaluated in differentiated cells. Although overall cycloheximide decreased both basal and stimulated cytokine secretion, the inhibitory effect of CsA persisted in all cases. Definition of abbreviations; CsA, cyclosporin A; IL-6, interleukin-6; PMA, phorbol myristate acetate.

\section{Discussion}

\section{Differentiation of the U937 cell line}

Study of the mechanis m of action of CsA on inflammatory cytokine production by human macrophages could have been carried out in tissue macrophages obtained ex vivo. However, the limited number of cells available for the different experiments, together with the difficulty involved in obtaining healthy control cells, within-group variability and, above all, the influence of the action of the drug on other cells - especially lymphocytes - counselled against this. Therefore, to study the mechanis $m$ of action of CsA on cytokine production in macrophages and to have available a sufficient number of cells, the possibility of using a monocyte cell line - namely, U937 cells - was implemented. This had the additional advantage of enabling study of a completely pure population; that is, completely excluding the presence of lymphocytes, which might alter the results obtained. The literature contains references to use of the U937 cell line in the evaluation of different macrophage functions. ${ }^{14}$ This human cell line grows continuously in suspension and was initially obtained from a pleural effusion in a patient with histiocytic lymphoma. ${ }^{15}$ Its phenotype corresponds to immature monocyte cells arrested in a differentiation state close to the myelomonocytic stem cell. ${ }^{15}$ It should be recalled that macrophages are highly differentiated cells and therefore have low proliferation capacity while cell lines show a strong duplication rate. Thus, the first step in this part of the work was to differentiate the human U937 monocyte cell line.

In the presence of several substances U937 cells undergo a process of differentiation and therefore acquire morphological and functional characteristics similar to those of macrophages. ${ }^{16}$ Since one of the interests in the present work was to study the effect of PMA on cytokine secretion, DMSO was chosen as a

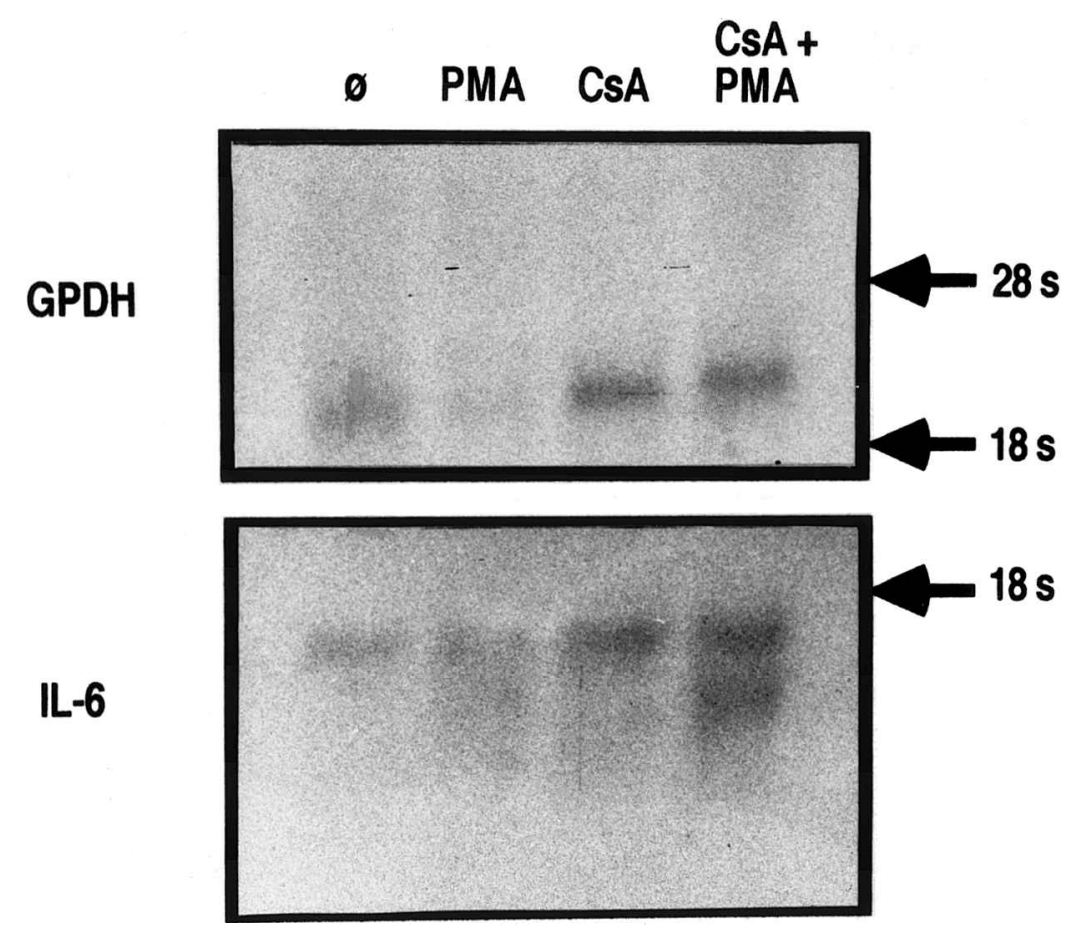

FIG. 3. Effect of CsA on IL-6 mRNA expression. Study of the action of CsA on IL-6 mRNA expression by Northern blot was carried out on the differentiated cell line under both basal and stimulated conditions. As seen, CsA did not affect IL-6 mRNA levels under either basal or stimulated conditions. Definition of abbreviations: CsA, cyclosporin A; GPDH, glyceraldehyde phosphate dehydrogenase; IL-6 interleukin-6; PMA, phorbol myristate acetate. 
diffe rentiating agent because it displays diffe re ntiating capacity on the U937 cell line. ${ }^{17}$ Differentiation was evaluated by kinetic, morphological, cytochemical and molecular techniques. The results obtained, which were similar to those reported by other authors, ${ }^{15,17}$ allowed us to conclude that the protocol used is indeed able to differentiate this cell line.

\section{Choice of cellular stimulus}

DMSO-differentiated U937 cells retain their capacity to be stimulated later on with different agents, ${ }^{17}$ among them PMA. ${ }^{18}$ It should be noted here that differentiation and activation are not incompatible concepts and that it is in fact possible to employ several substances ${ }^{16}$ to activate cells differentiated with other agents. Here, we evaluated the effect of three known macrophage stimulating agents and observed that for this purpose the most suitable agent was PMA at a concentration of $10^{-5} \mathrm{M}$. Although according to the literature lower concentrations of this substance are usually used, ${ }^{15,17}$ in each experimental system it is necessary to obtain evidence of the most effective concentration in the induction of a given effect. Therefore in the present study the aforementioned concentration was used. Although at this concentration PMA directly decreases cellular viability, from a quantitative point of view the increase that it induces in cytokine secretion cannot be attributed to the elimination of cytokines by dead cells.

\section{Production of interleukin- 6 by U937 cells}

Once the required experimental conditions had been established, IL-6 secretion by U937 cells was studied. The secretion of IL- 6 was stronger in differentiated than in undifferentiated cells. Recently it has been reported that the $\mathrm{CD} 4{ }^{19}$ and $\mathrm{CD} 23^{20}$ surface molecules present in differentiated MPS cells are involved in the secretion of IL-6 by U937 cells. Although none of them used a protocol identical to the one used here, different studies have documented the production of diffe rent inflammatory cytokines by these cells using bioassays, ${ }^{21}$ immunoassays ${ }^{22-25}$ or molecular biology techniques. ${ }^{21,24}$ Hass et a.$^{22}$ did not detect IL6 secretion, possibly due to the stimulation conditions, and the values described by Jiang et a . $^{23}$ for IL6 are lower than our own, although they used different protocols.

\section{Effect of CsA on interleukin-6 production}

Both in undifferentiated and differentiated U937 cells, at the highest concentration used used $(200 \mathrm{ng} / \mathrm{mL}) \mathrm{CsA}$ decreased stimulated secretion of IL-6, more than 50\%, a value similar to that reported by Moutbarrik et al. ${ }^{26}$ In human monocytes at therapeutic concentrations in vivo. Additionally, CsA decreased the intracellular concentration of IL-6. Accordingly, in the differentiated U937 cell line CsA can be said to decrease the production of inflammatory cytokines. The effect of CsA on the U937 cell line is not well documented. In a review of the literature no references to these phenomena were found.

\section{Mechanism of action of CsA on the production of interleukin-6}

From the theoretical point of view, the effect of CsA on the production of interleukin -6 could be due to a decrease in cell viability and proliferation and hence to a decrease in the number of producing cells, to the alteration of an early protein that would regulate the gene expression of cytokines, to a direct action on gene transcription, or to a modification of posttranscriptional events.

The data obtained here allow us to exclude a direct effect of CsA on cell prolife ration and viability. We can also exclude its action at early level since incubation with cycloheximide during the first hours of incubation did not affect the inhibitory effect of CsA. The expected decrease in IL-6 production by U937 cells due to the action of cycloheximide is consistent with the observations of other authors ${ }^{27}$ who have reported that this drug inhibits stimulation of IL-1 $\beta$ synthesis in the U937 cell line.

Finally, this immunomodulator does not alter IL-6 mRNA expression, allowing us to conclude that the effect of CsA on IL-6 production occurs at posttranscriptional level. Results similar to those obtained by us have been published by Kato et al. ${ }^{28}$ who observed that CsA scarcely affects the expression of the IL-6 gene in human peripheral blood monocytes. Likewise, in a murine mast cell line Nair et al. ${ }^{29}$ reported that CsA does not alter IL-6 mRNA expression although it does affect IL-3 mRNA. It would thus appear that in the human MPS CsA has little effect on the transcription of monokine genes since the mRNA levels of IL-1, ${ }^{30} \mathrm{TNF}^{30}$ and IL-8 ${ }^{31}$ are not affected by CsA either.

The exact mechanism by which CsA exerts its effect on cells of the MPS is not known although it has been suggested that its effect could be related to an inhibition of protein secretion/synthesis..$^{32,33}$ If, as commented earlier, it is true that CsA inhibits the secretion of inflammatory cytokines and does not affect the transcription of their genes, its action would appear to occur at post-transcriptional level.

In view of the decrease in immunogenic protein, CsA may act at some step between mRNA and synthesis of the protein. Although this aspect was not studied explicitly in the present work, the idea that CsA might act on intracellular membranes involved in protein synthesis could be entertained. At least three 
theoretical possibilities could be advanced to account for this. First, one could be dealing with a non-specific interaction, owing to the lipophilic nature of this immunomodulator. In this sense, it has been demonstrated that other lipophilic substances or lipid emulsions are able to inhibit cytokine production by macrophages through this mechanism. ${ }^{34}$ Second, although there is no consensus about the possibility, ${ }^{35,36} \mathrm{CsA}$ might inhibit prote in kinase $\mathrm{C}$ activity in macrophages. Thus, it has recently been observed that inhibition of this enzyme decreases TNF- $\alpha$ production in LPS-stimulated macrophages. ${ }^{37}$ Finally, another possibility would be that one would be dealing with a specific action derived from the interaction of CsA with cytokines associated with intracellular membranes. ${ }^{38}$ Further studies are evidently required to clarify all these aspects.

It should be noted that some authors have situated the site of action of CsA on monokine secretion at the level of release since they observed a decrease in the secretion of TNF- $\alpha$ w ith normal expression of the gene and normal intracellular cytokine synthesis. ${ }^{13}$ However, these studies were carried out in mouse MPS cells while those used here were from a human source.

Accordingly, it may be concluded that at therapeutic and non-toxic concentrations in vivo, CsA decreases the production of interleukin-6 by human macrophages at post-transcriptional level.

\section{References}

1. Fath man CG, Myers BD. Cyclosporine therapy for autoimmune disease. $N$ Engl J Med 1992; 326: 1693-1695.

2. Hess AD, Colombani PM, Esa AH. Cyclosporine and the immune response: basic aspects. Crit Rev Immunol 1986; 6: 123-149.

3. Schreiber SL, Crabtree GR. The mechanisnm of action of cyclosporin A and FK506. Imm unol Today 1992; 13: 136-142.

4. Ren K, Van Liew JB, Noble B. The effect of cyclosporin A on disease progression in proliferative immune complex glomerulonephritis. Clin Immunol Im munopathol 1993; 66: 107-113.

5. Hess AD. Mechanisms of action of cyclosporine: considerations for the treatment of autoimmune diseases. Clin Imm unol Im munopathol 1993; 68: $220-228$.

6. Chapman I, Mazzoni L. Mechanisms of inhibition by cyclosporin A on pulmonary leukocyte accumulation. Trends Pharmacol Sci 1994; 15: 99-101.

7. Ryffel B, Willard-Gallo KE, Tammi K, Loken MR. Quantitative fluorescence analysis of cyclosporine binding to human leukocytes. Transplantation 1984; 37: 276-280.

8. Mrowietz U, Christophers E. Effects of cyclosporine A treatment on psoriasis. I: Influence of low-dose cyclosporine on human monocyte function in vitro. Transplant Proc 1988; 20(Suppl 4): 53-57.

9. Losa JE, Mateos F, Jiménez A, Pérez JL. Action of cyclosporin A on mononuclear phagocytes. J Invest Allergol Clin Immunol 1996; 6: 222-231.

10. Losa JE, Mateos F, Martín MR, et al. Evaluation of inflammatory cytokine secretion by human alveolar macrophages. Mediat Inflamm 1999; 8: 43-51.

11. Tipton DA, Pabst MJ, Dabbous MK. Interleukin-1 beta- and tumor necrosis factor-alpha-independent monocyte stimulation of fibroblast collage nase activity. J Cell Biochem 1990; 44: 253-264.

12. Rofe AM, Philcox JC, Haynes DR, Whitehouse MW, Coyle P. Changes in plasma zinc, copper, iron, and hepatic metallothionein in adjuvantinduced arthritis treated with cyclos porin. Biol Trace Elem Res 1992;34: 237-248.

13. Nguyen DT, Eskandai MK, DeForge LE, et al. Cyclosporin a modulation of tumor necrosis factor gene expression and effects in vitro and in vivo. $J$ Immunol 1990; 144: 3822-3828.

14. Keicho N, Sawada S, Kitamura K, Yotsumoto H, Takaku F. Effects of an immuno-suppressant, FK506, on interleukin 1 alpha production by human macrophages and a macrophage-like cell line, U937. Cell Immunol 1991; 132: 285-294.

15. Minta JO, Pambrun L. In vitro induction of cytologic and functional differentiation of the immature human monocytelike cell line U-937 with phorbol myristate acetate. Am J Pathol 1985; 119: 111-126.

16. Öberg F, Botling J, Nilsson K. Macrophages and the cytokine network. Transplant Proc 1993; 25: 2044-2047.

17. Sakano T, Fujie A, Hamasaki T, Harada Y, Taniguchi H, Ue da K. Intracellular $\mathrm{Ca} 2+$ mobilization in immature and more mature U937 induced to differentiate by dimethyl sulfoxide or phorbol myristate acetate. Cell Immunol 1988; 111: 390-397.

18. Rzigalinski BA, Rosenthal MD. Effects of DMSO-induced differentiation on arachidonate mobilization in the human histiocytic lymphoma cell line U937: responsiveness to sub-mic romolar calcium ionophore A23187 and phorbol esters. Biochim Biophys Acta 1994; 1223: 219-225.

19. Taimi M, Dornand J, Nicolas M, Marti J, Favero J. Involve ment of CD4 in interleukin-6 secretion by U937 monocytic cells stimulated with the lectin jacalin. J Leukoc Biol 1994; 55: 214-20.

20. Paul-Eugene N, Amirand C, Ouaaz F, et al. Biochemical and functional alterations induced by $\mathrm{CD} 23$ ligation in the human promonocytic cell line U937. Im munology 1993; 80: 424-430.

21. Taimi M, Defacque H, Commes T, et al. Effect of retinoic acid and vitamin $\mathrm{D}$ on the expression of interleukin-1 beta, tumour necrosis factor-alpha and interleukin-6 in the human monocytic cell line U937. Im munology 1993; 79: 229-235.

22. Hass R, Lonnemann G, Mannel D, et al. Regulation of TNF-alpha, IL-1 and IL-6 synthesis in differentiating human monoblastoid leukemic U937 cells. Leuk Res 1991; 15: 327-339.

23. Jiang WG, Puntis MC, Hallett MB. U937 cells stimulated with opsonised zymozan particles provide a convenient laboratory source of tumour necrosis factor alpha. JIm munol Methods 1992; 152: 201-207.

24. Bosco MC, Gusella GL, Espinoza-Delgado I, Longo DL, Varesio L. Interferon-gamma upregulates interleukin-8 gene expression in human monocytic cells by a posttranscriptional mechanism. Blood 1994; 83 537-542.

25. Srivastava MD, Srivastava R, Srivastava BI. Constitutive production of interleukin-8 (IL-8) by normal and malignant human B-cells and other cell types. Leuk Res 1993; 17: 1063-1069.

26. Moutabarrik A, Takahara S, Namiki M, et al. Effect of FK 506 and cyclosporine on the expression of IL-6 and its receptor on stimulated monocytes. Transplant Proc 1993; 25: 2320-2321.

27. Berger AE, Carter DB, Hankey SO, McEw an RN. Cytokine regulation of the interleukin-1 receptor antagonist protein in U937 cells. Eur $J$ Im munol 1993; 23: 39-45.

28. Kato K, Yokoi T, Takano N, et al. Detection by in situ hybridization and phenotypic characterization of cells expressing IL-6 mRNA in human stimulated blood. J Im m unol 1990; 144: 1317-1322.

29. Nair APK, Hanh S, Banholzer R, Jirsch HH, Moroni C. Cyclosporin A inhibits growth of autocrine tumour cell lines by destabilizing interleukin-3 mRNA. Nature 1994; 369: 239-242.

30. Granelli-Piperno A, Ke ane M, Steinman RM. Evidence that cyclosporine inhibits cell-mediated immunity primarily at the level of the T lymphocyte rather than the accessory cell. Transplantation 1988; 46 (2 Suppl): $53 \mathrm{~S}-60 \mathrm{~S}$.

31. Mrowietz U, Sticherling M, Mielke V, Schroder JM, Christophers E. Neutrophil-activating peptide 1 /interleukin $8 \mathrm{mRNA}$ expression and protein secretion by human monocytes: effect of cyclosporin A. Cytokine 1991; 3: 322-326.

32. Roth J, Goebeler M, Erpenstein U, Sorg C. Differential regulation of the macrophage-specific surface antigen RM3/1 by cyclosporine, azathioprine, and dexame thasone. Transplantation 1994; 57: 127-133.

33. Pigatto PD, Bersani L, Altomare G, Mozzanica N, Finzi A. Effects of cyclosporin A on psoariatic monocyte functions and secretion. Acta Derm Venereol Suppl Stochk 1989; 146: 165-167.

34. Langadale LA, Maier RV, Wilson L, Pohlman TH, Williams JG, Rice CL. Liposome-encapsulated hemoglobin inhibits tumor necrosis factor release from rabbit alveolar macrophages by a posttranscriptional mechanism. J Leukoc Biol 1992; 52: 679-686.

35. Chiara MD, Bedoya F, Sobrino F. Cyclosporin A inhibits phorbol esterinduced activation of superoxide production in resident mouse peritoneal macrophages. Biochem J 1989; 264: 21-26.

36. Wenzel-Seifert K, Schachtele C, Hummel R, Grunbaum L, Seifert R. Evidence that inhibition of phorbol ester-induced superoxide anion formation by cyclosporin A in phagocytes is not mediated by direct inhibition of protein kinase C. Biochem Pharm a col 1994; 48: 859-864.

37. Tschaikowsky K. Protein kinase C inhibitors suppress LPS-induced TNF production in alveolar macrophages and in whole blood: the role of encapsulation into liposomes. Biochim Biophys Acta 1994; 1222: $113-121$.

38. Fruman DA, Burakoff SJ, Bierer BE. Immunophilins in prote in folding and immunosuppression. FASEB J 1994; 8: 391-400.

\section{Received 30 August 99; \\ accepted 24 September 99}




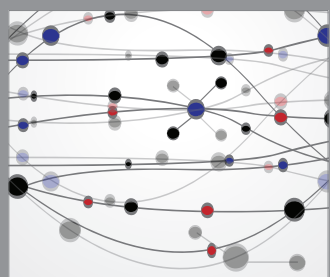

The Scientific World Journal
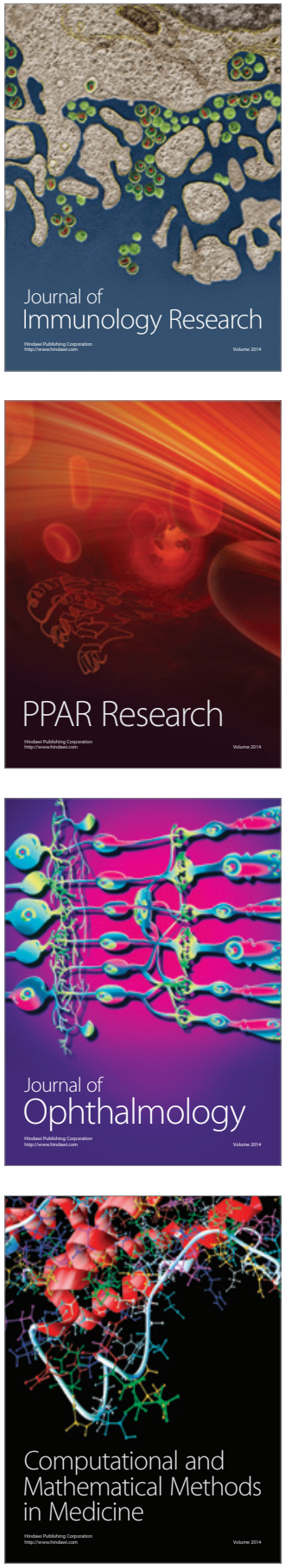

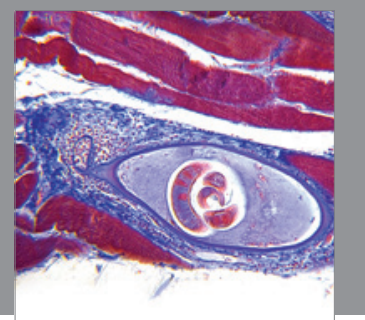

Gastroenterology

Research and Practice
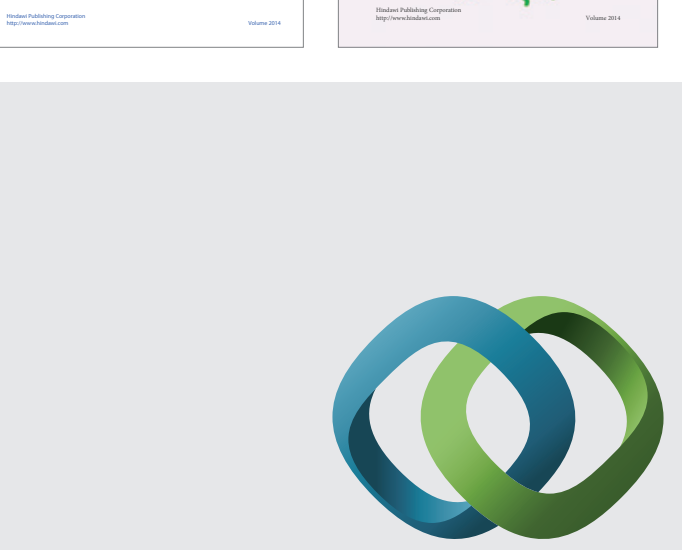

\section{Hindawi}

Submit your manuscripts at

http://www.hindawi.com
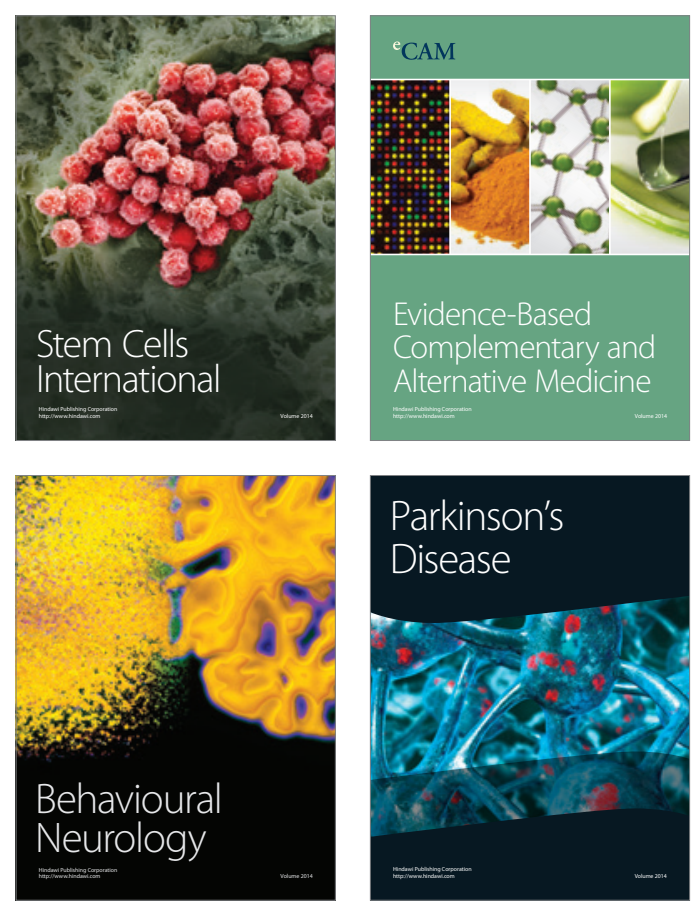

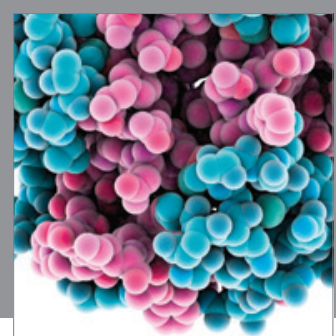

Journal of
Diabetes Research

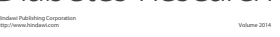

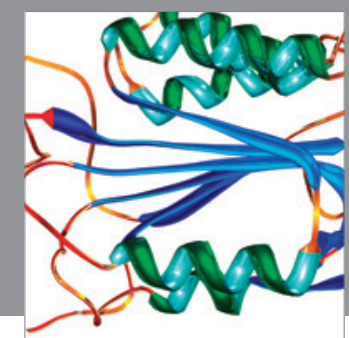

Disease Markers
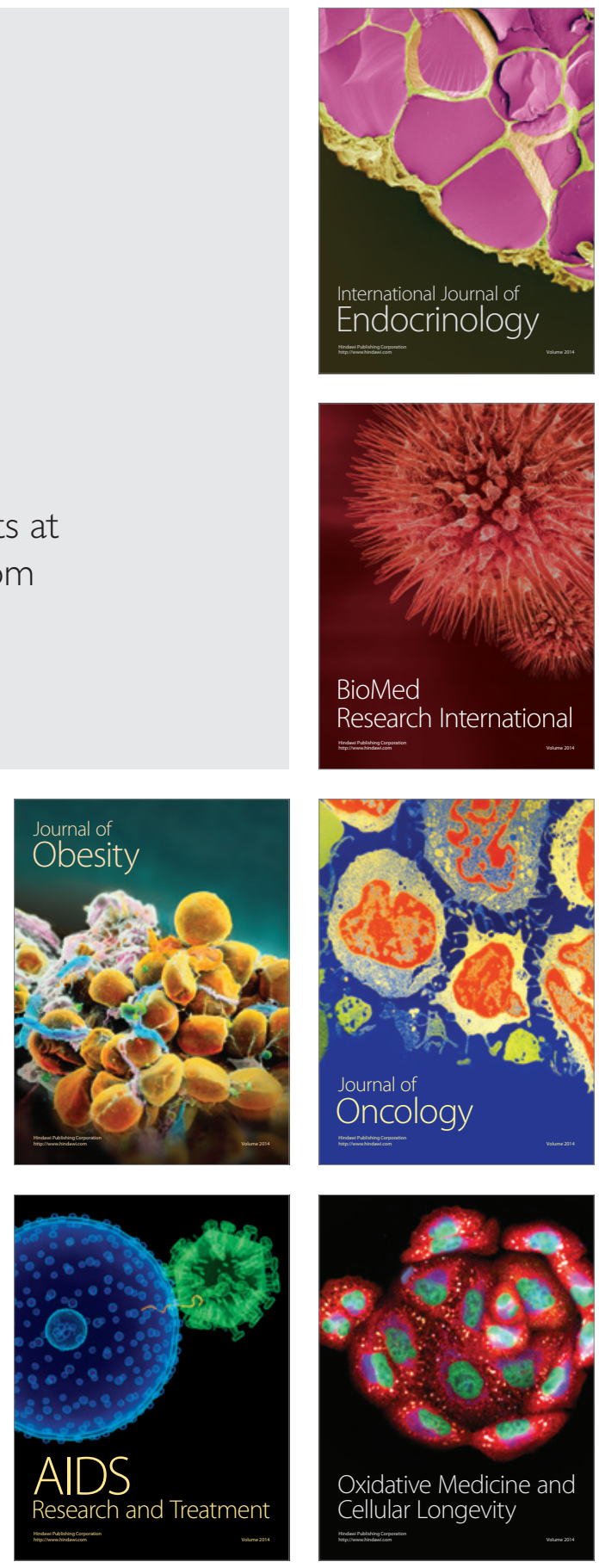